\title{
BIODIVERSITY ACCOUNTING OF CITIES: A CASE STUDY OF KOLKATA, INDIA
}

\author{
SOUPORNI PAUL \& SUCHANDRA BARDHAN \\ Department of Architecture, Jadavpur University, India
}

\begin{abstract}
The link between urban development and its impact on the environment is always debatable. The effects of urbanization on Indian cities have mostly resulted in the loss of natural ecosystems and deterioration of the urban environment. Biodiversity, as a significant parameter of an urban ecosystem, is essential for human society because of the goods and services it provides. UNEP's foresight report links biodiversity with urban sustainability and resilience, identifying it as one of the issues of 'The 21 Issues of 21st Century' under the section of food, biodiversity and land issues, which seems particularly important in the context of countries with developing economies. Since biodiversity conservation cannot happen in isolation, the ecological performance of urban areas with respect to biodiversity assumes high significance. In light of the IUCN Aichi Biodiversity Targets, the need for benchmarking the urban biodiversity status of the city of Kolkata (formerly Calcutta) in eastern India was, thus, strongly felt. A baseline study would also be a logical starting point for the adoption of a robust biodiversity strategy and action plan for Kolkata. This paper presents such an assessment, using the City Biodiversity Index as a tool, based on qualitative as well as quantitative approaches to acquire quantitative data on the populations of key biodiversity indicators. It also attempts to benchmark the current scenario for future conservation efforts and evaluate progress in the arresting rate of biodiversity loss in the city. The results of the study indicate a reasonable score in the variety of native biodiversity, courtesy of the rich natural history of Kolkata, while its performance in the proportion of natural areas and ecosystem services is relatively poor and demands attention.
\end{abstract}

Keywords: biodiversity, ecosystem services, urban environment, natural systems.

\section{INTRODUCTION}

Urban biodiversity, as a significant parameter of an urban ecosystem, is essential for the city as well as human society because of the goods and services it provides [1]. Despite the dependence of various economic sectors on biodiversity, such as agriculture, human health, business and industry etc., its global loss is considered to be one of the major environmental challenges of this century [2]. UNEP's foresight report [3] links biodiversity with urban sustainability and resilience, identifying it as one of the key issues of the 21 st century under the section of 'food, biodiversity and land issues'. In its issue no. 008 , it points out that while the traditional approach to preserving biodiversity tries to isolate nature from society, nature usually cannot, and should not, be isolated from humanity.

The ninth meeting of the Conference of Parties (COP9) to the Convention on Biological Diversity (CBD) in Bonn, Germany in 2008, acknowledged the role of cities and local bodies for the implementation of National Biodiversity Strategies and Action Plans (NBSAPs) in close collaboration with sub-national levels of government [4]. Rio Conventions (climate change and desertification) Decision IX/16 envisages that efforts at the national as well as local levels are of huge significance to maintain balance between improving biodiversity, fighting desertification/land degradation and climate change. The IUCN Aichi Biodiversity Targets document has laid out five strategic goals with a total of 20 targets under these where Target 2 calls for integrating biodiversity values into national /local development, poverty reduction strategies and planning processes. Similarly, Target 5 intends to substantially reduce the rate of loss, degradation and fragmentation of natural habitats. Target 14 
necessitates the restoration and conservation of ecosystems for indispensable services, with due attention given to relegated people and communities [5].

The implementation of strategies for enhancing urban biodiversity requires harmonization between the local authorities, and the global agenda needs to be connected to local issues. It is widely believed that the effects of urbanization on Indian cities have mostly resulted in the loss of natural ecosystems and deterioration of the urban environment. Since biodiversity, in general, is integral to sustainable development, and its cultural-cum-aesthetic value, in particular, is important in the context of urban areas, a robust biodiversity strategy and action plan at the city level can play a significant role in biodiversity conservation while helping in achieving these targets. It is, therefore, in the light of the above global concerns and mandates that the current study has been taken up for the Indian city of Kolkata (formerly Calcutta). Located on the eastern bank of River Hooghly, Kolkata - the capital of the state of West Bengal and the third largest city of India - has largely been a linear city extending mostly along the north-south axis. Once bestowed with rich biological diversity and efficient natural systems within the city, it is considered to be an 'environmentally subsidized' city [6]. The River Hooghly on the west and the vast stretch of salt water marshes on the east, as indicated in Fig. 1, have not only articulated the urban growth of Kolkata, but also play a major role in its infrastructure, sustenance and liveability by providing ecosystem services, preserving natural habitat and fulfilling the recreational need of its residents. Kolkata has been reported to have more than 230 species of birds, 600 species of plants and 110 species of butterflies [7]. With a current population density of around $24,252 \mathrm{~km}^{2}$ [8], it experiences everincreasing pressure on its natural systems and resources due to its growing footprint and continuous infrastructural augmentation to meet the apparent developmental needs. Like many other cities, it suffers from the urban environmental challenges of biodiversity loss, deforestation, pollution, land-use changes and over-exploitation of natural systems, resulting in their deterioration, thus limiting the benefits of urban infrastructure. Hence, urban infrastructure systems need to be designed for greater resource efficiency by integrating biodiversity and other natural assets for improved liveability and sustainability. The precise monitoring of urban biodiversity and ecosystem services is a step in that direction that would involve inventorying the existing natural stock by establishing its current baseline biodiversity status. The City Biodiversity Index (CBI), also known as the Singapore Index, has been used here as a tool to assess the current biodiversity status in the city of Kolkata. This index, taken intermittently after regular intervals, may be used to observe the improvement of their conservation against their own individual baselines and signify the progress of the city in the path of sustainable development [9]. The present study is based on qualitative and quantitative methods to acquire data on key biodiversity indicators of Kolkata. Technical and administrative hurdles, such as the paucity of data, the delineation of spatial territories and the authenticity of information, were faced during the course of this study, and are discussed in detail under the relevant sections.

\section{METHODOLOGY}

The CBI is a potentially useful set of standardized indicators for the assessment and periodic monitoring of biodiversity status. Thus, it was decided to follow the baseline study of indicators on the CBI framework as adopted by many other cities.

The study was carried out for approximately two years to estimate values for the 23 indicators, mainly from secondary data consisting of aerial maps, field surveys, literature reviews from documents published by government and non-government agencies, and structured interviews with ecologists, academicians, activists and government officials involved in biodiversity activities. However, many challenges were faced during the data 
collection stage. Most of the findings are based on existing research and interviewee's responses; hence, incorrect information may lead to marginal error. Biodiversity in most Indian metropolitan cities has generally been overlooked; therefore, there was a lack of methodically compiled information in one place. Also, the existing data is separated in different sources and is not always compatible. Access to important data was often hindered by the absence of transparency of public administrations and the absence of a complete and meticulous study at the scale of the city. The detailed suite of methodologies for the collection and analysis of data for each component are listed in the following sections.

\subsection{Native biodiversity}

For assessing the proportion of natural areas, satellite images were digitized and data matched with those available from the existing land-use maps, a source book by the Kolkata Municipal Corporation (KMC) [10] and published research [11], [12], before the final figure was derived. Although the fragmentation of natural areas is one of the main threats to biodiversity, connectivity measures or ecological networks in the city of Kolkata are not properly defined; hence, it was not possible to measure at this stage. The 'Maidan' and its surroundings, the largest open space in the core of the city, has been considered as the only protected natural open space in the city core.

A list of species of biodiversity indicators (birds, butterflies and vascular plants) was attained from the Peoples Biodiversity Register (PBR) [13], recently published by the West Bengal Biodiversity Board (WBBB), books and publications by Ecologists and Academicians [14]-[26]. Some of these data encompass the larger metropolitan region, namely the Kolkata Metropolitan Area (KMA), so necessary analyses were carried out to note the species available in the KMC area. Authors are grateful to renowned ecologist, Dr A.K. Ghosh, (Director at the Centre for Environment and Development, and former Director for the Zoological Survey of India) and the key person responsible for formulating the PBR and Dr S. Ghosh (environmentalist) for their support and guidance. For Vascular Plants, A.P. Benthall's monumental book Trees of Calcutta and its Neighbourhood [27] was referred to, along with other recent publications [14], [28]-[30], since many plants have been introduced or removed from the Kolkata environs. The remaining indicators (reptiles and amphibians) were considered for their importance in the urban ecosystem [31]. Although Kolkata has a very rich variety of Pisces, this class was avoided because many of them are introduced species.

\subsection{Ecosystem services provided by biodiversity}

Information on natural resources (water, energy and land) was collected from the existing literature, urban local bodies, government authorities and other agencies. For the regulation of quantity of water (Indicator 11), the proportion of all open terrestrial areas (excluding wetland areas) was considered. But in reality, vegetation and permeable surfaces in all forms, e.g. parks, lawns, roadside greenery, rivers, green roofs, private gardens etc., can help with ground water recharge and reducing the rate of surface flow. Hence, it would have been more appropriate to consider the amount of all porous areas but this was not practically possible to quantify. For climate regulation services, aerial maps of tree canopy cover and related publications [32] were used as an indirect measure of the cooling effect of vegetation, carbon sequestration and storage. Similarly, climate regulation can also be affected by many factors, e.g. size and foliage characteristics of trees, but only canopy cover has been considered for 
the study. For Indicator 13 (area of parks), information was extracted from unpublished reports by ENDEV [33] and KMC's list of parks and playgrounds [34].

\subsection{Governance and management of biodiversity}

The total budget allocated for environment and biodiversity management by a city administration is a representation of the city's commitment towards environmental awareness. Biodiversity-related activities and budgets were intermingled within other sectors of city administration and were difficult to segregate and report. For Kolkata, there was no budget dedicatedly allocated for biodiversity-related activities. Hence, the financial plan under "Parks and Gardens" of the total Annual Budget [35] was considered for calculation on the index. Similarly, there is no account of biodiversity-related projects in the city, but a considerable amount of work is being done for the improvement of the city's environs, such as waterfront development, the rejuvenation of grey areas of the city or the greening of avenues, which indirectly enhances biodiversity [36], [37]. A large number of nongovernment organizations (NGOs) and independent environmental activists are working within the city. They carry out awareness programs round the year, records of which are available from the respective organizations.

\subsection{Calculation of scores and index}

The numerical values of each indicator have been quantified and reported, followed by the application of the 4-point CBI scores to only the selected indicators that have fixed absolute figures, viz. the physical areas and governance and management. The available data on species have been found to span over decades and a large number of species were introduced or removed over these years, which are not properly documented. So, after many levels of analyses, the list of existing species as of today are obtained and stated as baseline data, for which scores are not applicable for the current study. A time span of 3-5 years for this academic exercise has been considered inadequate for monitoring significant change in the number of native indicator species or in population sizes and ranges, for which long-term monitoring is required to account for the changes due to urban sprawl, loss of natural ecosystems, pollution and other anthropogenic factors.

\section{ASSESSMENT OF THE CITY BIODIVERSITY INDEX (CBI) OF KOLKATA}

\subsection{Profile of the city}

\subsubsection{Location and size}

Kolkata $\left(22^{\circ} 28^{\prime} 003^{\prime \prime} \mathrm{N}\right.$ to $22^{\circ} 37^{\prime} 303^{\prime \prime} \mathrm{N}$ latitude and $88^{\circ} 17^{\prime} 303^{\prime \prime} \mathrm{E}$ to $88^{\circ} 25^{\prime} 003^{\prime \prime} \mathrm{E}$ longitude) is the capital of the state of West Bengal and the most important city in eastern India. Kolkata is bordered by the river Hooghly in the north-east, South 24 Parganas district in the south and south-west, Salt Lake City in the east and North 24 Parganas district in the north. Kolkata lies in a formerly swampy area and its altitude is $9 \mathrm{~m}$ above the mean sea level. Its inter- and intra-city connectivity network includes commercial and military ports, an international airport, an underground metro and a suburban railway.

The KMA, with an area of $1886.67 \mathrm{~km}^{2}$, falls under the jurisdiction of the Kolkata Metropolitan Development Authority (KMDA). The KMC is the centre of the metropolis and covers a total area of $185 \mathrm{~km}^{2}$, which is just over $10 \%$ of the metropolitan area. The KMC area has grown over the years by the annexation of suburban areas. The jurisdiction of KMC now covers 15 boroughs which are subdivided in 141 wards [10]. 


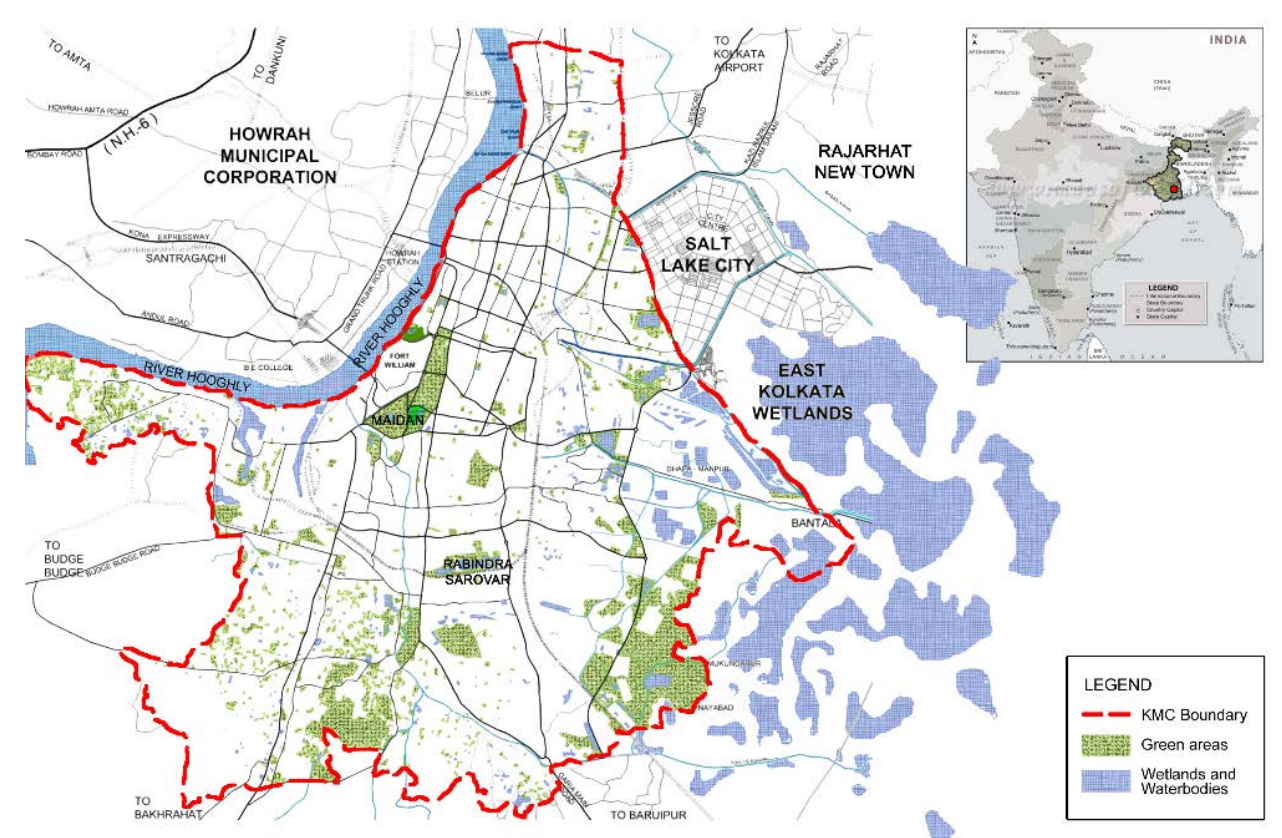

Figure 1: Kolkata Municipal Corporation (KMC) area and its surroundings. (Source: http://www.indmaps.com/)

\subsubsection{General introduction and early history}

Kolkata was once the administrative capital of British India, and today its urban planning and land-use structure are greatly influenced by its past colonial rule. Geographically, Kolkata was mostly a remote, marshy land within the lower Gangetic delta of eastern India and was considered to be an extension of the Sundarbans [38]. About three and a quarter centuries ago, it started changing rapidly with the arrival of the English East India Company in 1690. The year also marked the beginning of Kolkata's recorded history [10]. The growth of Kolkata has always been constrained with the dominating Hooghly River on the west and the vast expanses of salt water swamps on the east acting as natural boundaries. The first English settlement grew up surrounding the modern Dalhousie Square, whose tank (then called "The Great Tank") was the principal source of water supply [39]. Trade began to flourish, and Kolkata gained more and more importance as a commercial city. People from other parts of Europe as well as from China, Iran, and Armenia flocked in huge numbers. The British started expanding the city towards the east by reclaiming the wetlands, since expansion on the west was not possible due to the presence of Hooghly River [11], [39]. The early 1920s marked a major phase of urban planning with the Calcutta Improvement Trust (previously CIT, now KIT) acquiring large tracts of marshy jungles to the south of the city for residential use improving roads, creating lakes and parks. After Independence in 1947 and followed by the Partition of Bengal, Kolkata faced a huge influx of population and unprecedented urban growth [11]. Over the years the salt water lakes have been reclaimed for the expansion of the city. In the 1960s, Salt Lake City was created reclaiming a large chunk of salt water lakes (hence the name). In the following two decades, large expanses of wetlands were encroached 
upon for the expansion of the city. In the 1970s and 1980s, the East Kolkata Township and Baishnabghata-Patuli Township were developed, converting huge acres of wetlands. In the late 1990s, yet another township called the New Town was commissioned in Rajarhat, further extending the limits of the city towards the east.

\subsubsection{Geographical profile}

Built on flat sedimentary marshy land, Kolkata has been gifted with moist deciduous vegetation and tropical wetlands, most of which has been converted for aquaculture. On the west bank the land slopes towards the Hooghly River, which is a tributary of the River Ganga. On the east bank the land slopes in the reverse direction, away from the river and down to the low-lying marshes and wetlands to the east. Kolkata is folded with alluvial soil [40].

Kolkata has a tropical wet-and-dry climate (according to Koppen's climatic classification). The climate is mostly warm and humid throughout the year. From March through September, Kolkata is hot and humid, with an average temperature of $29^{\circ} \mathrm{C}\left(85^{\circ} \mathrm{F}\right)$ and reaching as high as $38^{\circ} \mathrm{C}\left(100^{\circ} \mathrm{F}\right)$ in May and June. Winters are mild, with an average January temperature of $19^{\circ} \mathrm{C}\left(67^{\circ} \mathrm{F}\right)$ and a minimum of $10^{\circ} \mathrm{C}\left(50^{\circ} \mathrm{F}\right)$. Average annual rainfall is $1625 \mathrm{~mm}$ (64 inches) from June through September. The highest rainfall occurs during the monsoon season in August, at $306 \mathrm{~mm}$ [41].

\subsubsection{Demographics}

As per provisional reports by the Census of India 2011 [8], the population of Kolkata city is 4,496,694; of which males and females number 2,356,766 and 2,139,928 respectively. The population density is 24,252 persons per $\mathrm{km}^{2}$, which makes it the $3 \mathrm{rd}$ largest metropolis in India. The total population of KMA is $14,112,536$, with a population density of 7480 per $\mathrm{km}^{2}$.

\subsubsection{Economic parameters}

Kolkata is the main commercial and financial centre of eastern India and the main port of communication for the north-east Indian states. Kolkata is home to a major port, an international airport, India's oldest and second-largest stock exchange, IT hubs, various medium- and small-scale industries, and many reputed academic institutions. According to Pricewaterhouse Cooper's report, as of 2009, Kolkata's economic output as measured by Gross Domestic Product (GDP) was 104 USD, and as of 2010, with an estimated GDP by Purchasing Power Parity (PPP) of 150 billion USD. With its huge economy and cheap living expenses, it ranked third among South Asian cities, after Mumbai and Delhi, and one of the World's major centres of business in GDP-PPP terms [42], [43].

\subsubsection{Biodiversity features}

Located within the floodplains of lower Gangetic delta, Kolkata is naturally gifted with rivers, canals, wetlands, waterbodies and lush tropical landscapes. The East Kolkata Wetlands, a Ramsar site, also known as the 'Kidney of Kolkata' serves multiple ecological functions - acting as the city's waste water sink while adding to urban resilience by preventing induced flooding, maintaining the groundwater table, regulating the nutrient cycle and micro-climate and home to a diverse variety of flora and fauna. This natural marsh formation is a wonder of nature, supporting the world's largest and oldest integrated resourcerecovery practice based on a combination of agriculture and aquaculture. It provides livelihoods to a large economically underprivileged population.

Other than innumerable water bodies scattered around the city, there is one National lake

- Ravindra Sarovar in south Kolkata - which is man-made and rain-fed. A major 
environmental reserve with huge amenity and recreational value, the lake ecosystem plays a key role in urban ecology and social benefit. As with other water bodies, the pressures of increased human activities have led to the deterioration of the environmental components, especially the lake's water quality.

'Maidan', 620 hectares of open green space in the heart of the city, is referred to as the "lungs" of the city and constitutes 61 per cent of Kolkata's public open space. Along with other adjoining parks, it is the hub of major recreational and sports activities, a green belt and repository of biodiversity. Other than these natural ecosystems, Kolkata has some man-made nature reserves in and around the city, which have been somewhat able to retain their own ecosystems, helping in conserving biodiversity and regulating ecosystem services. The Acharya Jagadish Chandra Bose Indian Botanic Garden (in Howrah), Alipore Zoological Garden, Agri-Horticultural Society and Chintamoni Kar Bird Sanctuary are home to a large number of rare and threatened species of plants and animals. Certain historic garden precincts around Government buildings, museums and other institutions also contribute towards enhancing the biodiversity of the city. Isolated pockets of other anthropogenic green spaces have also added nature in favour of the city.

Thus, Kolkata had reported a reasonably rich biodiversity mainly because of this natural heritage. Benthall [27] provided an excellent account of as many as 276 species of trees that were found up to 1944, of which he identified 61 species as endemic, 69 as naturalised in the neighbourhood of the city, 41 as truly indigenous, 20 as native of other parts of India and 6 species introduced from North America and one each from Malaya and Africa. The indigenous varieties include Ficus benghalensis (Banyan), Ficus religiosa (Peepal), Mangifera indica (Mango), Acacia arabica (Beng. Babul), Syzygium cumini (Black Plum, Beng. Kalojam), Ficus hispida (Beng. Dumur), Putranjiva roxburghii (Child-life Tree) and Azadirachta indica (Neem). But years of 'development' has led to changes in the species diversity and the most recent account [29] reveals that at least 21 per cent of the species have disappeared from the cityscape within a span of 64 years; whereas, the total tree species diversity has increased from 276 to 294 . The data from the survey conducted by Dr S. Ghosh and her team from 2006 to 2010 [14], if compared with that of Benthall, shows that 58 of the 276 species have disappeared from the cityscape, of which 12 were indigenous species. Some 76 species have been introduced in the same period, which gives a total of 103 indigenous species and 80 exotic species. The removed species include Tamarix gallica (Beng. Jhau), Garcinia cowa (Beng. Kau), Pterospermum suberifolium (Beng. Muchukundu), Grewia glabra (Beng. Kath bimla), Sapindus mukorossi (Beng. Bararitha), Sesbania sesban (Beng. Jayanti), Erythrina ovalifolia (Beng. Hari kakra), to name a few [29].

Out of 1501 species of butterflies recorded from India, Dr S. Ghosh [14] reports that 84 of them are available in Kolkata. A large number of the butterflies like the Common Mormon, Tailed Jay, Common Jay, Common Emigrant, Psyche, Common Gull, Common Grass Yellow, Peacock Pansy and Blue Tiger are most common. Throughout the year at least 70-75 bird species appeared to be present in and around Kolkata. These could be considered as the resident or local migrant birds of Kolkata urban area [26]. Birds like Pallas's Fishing Eagle and Vultures are no longer seen due to the absence of large, tall trees appropriate for nesting. A large population of Gull was regularly seen in Brace Bridge wetlands. Wagtail and Pipit roosting in emergent vegetation were also seen. Since such areas have been cleared, they have been deprived of their roosting site. In the Alipore Zoological Gardens, a few pairs of Darter were found in the 1980s but they are no longer there. Common Wood Shrike was seen in Chintamani Kar Bird Sanctuary in large numbers, but now they are seen no more. House Crow and Black Kite increased in population, possibly due to the accumulation of garbage in the city. The migratory water birds that used to visit the city's zoological gardens 
have now moved away to another waterbody a few kilometres away from the city, probably due to the high-rise buildings around the zoo, paving of the banks, as well as an increase in vehicular traffic causing noise and air pollution [14], [26]. Moreover, many birds that were visible in the last century have been found to be vulnerable and locally extinct at present. However, recently, a new species of mammal has been reported in Salt Lake, within the urban environment of Kolkata, and has come to be known as the Salt Lake Marsh Mongoose.

\subsubsection{Administration of biodiversity}

Several government organizations and NGOs are involved in the governance and management of biodiversity conservation efforts in various capacities, and some NGOs, in particular, are very active in and around Kolkata. They work independently or in collaboration in research, critical reporting, protecting the urban greenery from encroachment or deterioration, creating awareness and imparting training among the masses, policy research and publications. The Department of Environment, Government of West Bengal, Kolkata Environmental Improvement Project (KEIP), Institute of Environmental Studies and Wetland Management (IESWM), and West Bengal Biodiversity Board (WBBB) are some of the public offices working in this area, while the Centre for Environment and Development (CED), Centre for Contemporary Communication (CCC), Nature Mates Nature Club and Prakriti Samsad are some noteworthy NGOs at the forefront of biodiversity conservation activities. A complete list of such organizations with their respective web-links has been prepared as part of the baseline study and regular updating is being carried out to make the list as exhaustive as possible.

\subsection{Calculation of the Singapore Index on Cities' Biodiversity}

Table 1 presents the summary and results of the current study, comprising a comprehensive biodiversity survey of Kolkata as part of its application of the CBI, in an attempt to develop a self-assessment tool for the city authorities and all other stakeholders for the improved management of urban biodiversity.

\section{CONCLUSION}

In light of the international biodiversity targets, this paper presents a baseline account of the urban biodiversity status of the city of Kolkata with the help of the CBI, in order to benchmark it for periodic self-assessment by the concerned stakeholder/s. Based on the index and performance of the indicators, Kolkata can be considered a "Brown city in Green Background". Kolkata shows a good score in the indicators of native biodiversity. This is mainly because of the natural history of the city and also due to the existence of the ecologically rich East Kolkata Wetlands in the vicinity. But, gradually, the city is losing a huge number of native plants due to random deforestation, urban sprawl and the introduction of exotic species. The loss of greenery from the environs of the city has resulted in the habitat loss of many species of wildlife and micro fauna. The rich ecological background of the city is not elucidated properly and seems to be inadequately addressed during the preparation of the master plans. Hence, performance in the proportion of natural areas and ecosystem services is relatively poor and needs immediate attention as well as prioritization. Only a small number of Kolkata's many natural areas are protected, and are mostly disconnected. Dr Ghosh [29] estimated only 5.5\% of the city's area constitutes parks, gardens and open spaces, while the ideal share should be $15 \%$ for a city of Kolkata's size. The indicators related to governance and management showed that the concept of biodiversity is still relatively 
Table 1: List of indicators and their estimated value.

\begin{tabular}{|c|c|c|c|c|}
\hline $\begin{array}{l}\text { Core } \\
\text { components }\end{array}$ & Sr. no. & Indicators & Estimated value & Score \\
\hline \multirow{10}{*}{$\begin{array}{l}\text { Native } \\
\text { biodiversity in } \\
\text { the city }\end{array}$} & 1 & Proportion of natural areas in the city & $8 \%$ & 2 \\
\hline & 2 & Connectivity measures & $\mathrm{n} / \mathrm{a}$ & - \\
\hline & 3 & $\begin{array}{l}\text { Native biodiversity in built-up areas (bird } \\
\text { species) (baseline data) }\end{array}$ & 64 & \multirow{6}{*}{$\begin{array}{l}\text { Baseline } \\
\text { data, } \\
\text { hence no } \\
\text { score }\end{array}$} \\
\hline & 4 & Number of vascular plant species (baseline data) & 667 & \\
\hline & 5 & Number of bird species (baseline data) & 230 & \\
\hline & 6 & $\begin{array}{l}\text { Number of butterfly species } \\
\text { (baseline data) }\end{array}$ & 110 & \\
\hline & 7 & $\begin{array}{l}\text { Number of reptile species } \\
\text { (baseline data) }\end{array}$ & 40 & \\
\hline & 8 & Number of amphibian species (baseline data) & 12 & \\
\hline & 9 & Proportion of protected natural areas & 0.021 & 1 \\
\hline & 10 & Proportion of invasive alien species & $\mathrm{n} / \mathrm{a}$ & - \\
\hline \multirow{4}{*}{$\begin{array}{l}\text { Ecosystem } \\
\text { services } \\
\text { provided by } \\
\text { biodiversity }\end{array}$} & 11 & Regulation of quantity of water & 0.11 & 1 \\
\hline & 12 & $\begin{array}{l}\text { Climate regulation: carbon storage and cooling } \\
\text { effect of vegetation }\end{array}$ & $4.8 \%$ & 1 \\
\hline & 13 & $\begin{array}{l}\text { Recreation and education: area of parks with } \\
\text { natural areas }\end{array}$ & $\begin{array}{l}0.94 \mathrm{ha} / 1000 \\
\text { persons }\end{array}$ & 4 \\
\hline & 14 & $\begin{array}{l}\text { Recreation and education: number of formal } \\
\text { education visits per child below } 16 \text { years to } \\
\text { natural areas per year }\end{array}$ & $\mathrm{n} / \mathrm{a}$ & - \\
\hline \multirow{9}{*}{$\begin{array}{l}\text { Governance } \\
\text { and } \\
\text { management } \\
\text { of biodiversity }\end{array}$} & 15 & $\begin{array}{l}\text { Budget allocated to biodiversity } \\
(2015-2016)\end{array}$ & $0.05 \%$ & 1 \\
\hline & 16 & $\begin{array}{l}\text { Number of biodiversity projects implemented by } \\
\text { the city annually }\end{array}$ & $<4$ & 1 \\
\hline & 17 & $\begin{array}{l}\text { Existence of local biodiversity strategy and } \\
\text { action plan }\end{array}$ & No & 0 \\
\hline & 18 & $\begin{array}{l}\text { Institutional capacity: number of biodiversity- } \\
\text { related functions }\end{array}$ & $>3$ & 4 \\
\hline & 19 & $\begin{array}{l}\text { Institutional capacity: number of city or local } \\
\text { government agencies involved in inter-agency } \\
\text { cooperation pertaining to biodiversity matters }\end{array}$ & $>5$ & 4 \\
\hline & 20 & $\begin{array}{l}\text { Participation and partnership: existence of } \\
\text { formal or informal public consultation process }\end{array}$ & N/A & 0 \\
\hline & 21 & $\begin{array}{l}\text { Participation and partnership: number of } \\
\text { agencies/private companies/NGOs/ academic } \\
\text { institutions/ international organizations with } \\
\text { which the city is partnering in biodiversity } \\
\text { activities projects and programs }\end{array}$ & $7-12$ & 2 \\
\hline & 22 & $\begin{array}{l}\text { Education and awareness: is biodiversity or } \\
\text { nature awareness included in the school } \\
\text { curriculum }\end{array}$ & Included & 4 \\
\hline & 23 & $\begin{array}{l}\text { Education and awareness: number of outreach or } \\
\text { public awareness events held in the city per year }\end{array}$ & $1-59$ & 1 \\
\hline \multicolumn{4}{|c|}{ Total baseline score of Kolkata in 2017} & 26 \\
\hline
\end{tabular}


unfamiliar to planners, academicians and professionals; hence, planning policies seem to be failing to achieve the desired levels of biodiversity integration. Knowledge about local biodiversity is weak and fragmented. Although the first PBR at a city level in India has been published in Kolkata, the general public are unaware of its existence and importance, possibly due to its unavailability in the public domain. The current amount of funds allocated for safeguarding and managing biodiversity has also been found to be grossly insufficient. The study establishes the need for the formulation and adoption of a robust biodiversity strategy and action plan for Kolkata, which certainly has a lot of potential in fulfilling specific biodiversity objectives in several key areas of the city. One of the ways to enhance urban biodiversity and protect the natural elements of the city is by implementing green corridors that connect natural pockets. Kolkata offers plenty of opportunities in the form of its predominant linear elements, both natural and anthropogenic, such as the river, the canal network criss-crossing the city, roads, bridges and other transport corridors. Innovative planning interventions with an ecological approach can substantially prevent the loss of the biotic environment while augmenting the existing landscape resources. The gradual scaling up of such planned pro-environmental interventions and increasing the green cover along with qualitative upgradation of natural resources such as the existing water bodies and parks would certainly have a positive impact on the city's biodiversity index, as well as its urban future.

\section{REFERENCES}

[1] TEEB - The Economics of Ecosystems and Biodiversity, TEEB Manual for Cities: Ecosystem Services in Urban Management, pp. 1-2, 2011.

[2] Cities and Biodiversity Outlook, Action and Policy: A Global Assessment of the Links between Urbanization, Biodiversity, and Ecosystem Services, pp. 7-10, 2012.

[3] UNEP, Summary Report on UNEP Foresight Process 2011-21: Issues for the 21st Century. Proceedings of the Global Conference on Land-Ocean Connections, Manila, 2012.

[4] National Parks Board, User's Manual for The City Biodiversity Index (also known as the City Biodiversity Index), Singapore, pp. 1-2, 19-20, 2014.

[5] WHO, Our Planet, Our Health, Our Future, Human health and the Rio Conventions: Biological Diversity, Climate Change and Desertification, pp. 2-3, 2012.

[6] Mazumder, A., Implications of converting wetlands into buildable areas (case: East Kolkata Wetlands), M. Planning Thesis Report, School of Planning and Architecture, New Delhi, India, p. iii, 2012.

[7] ENDEV, Society for Environment \& Development, Report on status of Calcutta's parks and gardens with an integrated management plan, Kolkata, 2002.

[8] Census of India: Provisional Population Totals for Census 2011: West Bengal. Online. http://censusindia.gov.in/2011-prov-results/prov_data_products_wb.html. Accessed on: 30 Sep. 2016.

[9] Chan, L., Measuring Biodiversity in Cities: The Singapore Index on Cities' Biodiversity, National Biodiversity Centre, National Parks Board Singapore, 2010.

[10] Chakraborty, C., A Source Book on Environment of Kolkata, Kolkata Environmental Improvement Project, Kolkata Municipal Corporation, p. 14, 2013.

[11] Mukherjee, M., Urban growth and spatial transformation of Kolkata metropolis: A continuation of colonial legacy. ARPN Journal of Science and Technology, 2(Special Issue), pp. 80-98, 2012.

[12] Rajashekariah, K., Urbanisation and Impact on Ecological Systems: Impact of Urbanisation on Biodiversity: Case Studies from India, WWF-India, pp. 27-37, 2011. 
[13] ENDEV, Society for Environment and Development, People's Biodiversity Register: Kolkata, 2012.

[14] Ghosh, S., Urban Biodiversity of Calcutta: Flowering Plants, Butterflies, Birds and Mammals, Zoological Survey of India: Kolkata, India, 2010.

[15] Ghosh, S. \& Siddique, S., Butterfly diversity in and around urban Kolkata. Rec. Zoological Survey of India, 104(3-4), pp. 111-119, 2005.

[16] Ghosh, S. \& Ghose, P.S., New record of birds from Kolkata metropolitan area and its environs. Rec. Zoological Survey of India, 107(4), pp. 17-25, 2007.

[17] Ghose, P.S. \& Santra, S.C., Pattern of avian diversity in urban environment: A case study in Kolkata. Zoological Research in Human Welfare, pp. 127-148, 2008.

[18] Ghosh, S., Birds and Butterflies in the Grounds of the Raj Bhavan Kolkata, 2009.

[19] Chowdhury, R., Sarkar, S., Nandy, A. \& Talapatra, S.N., Assessment of bird diversity as bioindicators in two parks, Kolkata, India. International Letters of Natural Sciences, 16, pp. 131-139, 2014.

[20] Mookherjee, K., Birds and Trees of Tolly, Tollygunj Club Ltd.: Calcutta, 1995.

[21] Mookherjee, K., Birds in and around Kolkata. Naturalist, III, pp. 4-14, 2004.

[22] Mukherjee, S., Banerjee, S., Saha, G.K., Basu, P. \& Aditya, G., Butterfly diversity in Kolkata, India: An appraisal for conservation Management. Journal of Asia-Pacific Biodiversity, 8, pp. 210-221, 2015.

[23] Nair, A.V., Mitra, P. \& Bandyopadhyay, S.A., Studies on the diversity and abundance of butterfly (Lepidoptera: Rhopalocera) fauna in and around Sarojini Naidu college campus, Kolkata, West Bengal, India. Journal of Entomology and Zoology Studies, 2(4), pp. 129-134, 2014.

[24] Roychowdhury, D.K., Birds in and around Calcutta Metropolitan Area. Naturalist, 1, pp. 7-16, 1984.

[25] Sengupta, S., Mondal, M. \& Basu, P., Bird species assemblages across a rural urban gradient around Kolkata, India. Urban Ecosystems, Jun. 2013.

[26] Poddar, A. \& Ghosh, A.K., Birds of Kolkata and its vicinity: Historical and current perspectives. Environ, XIII(1), pp. 61-64, 2014.

[27] Benthall, A.P., Trees of Calcutta and its Neighbourhood, Thacker Spink and Company Ltd.: London, 1958.

[28] Chakravarty, R.K. \& Jain, S.K., Beautiful Trees and Shrubs of Calcutta, Botanical Survey of India, 1984.

[29] Ghosh, A.K., Samling, C.L., Ghosh, S. \& Chatterjee, N.N., Changes in the tree species diversity in Kolkata: 1946-2010. Indian Journal of Landscape Systems and Ecological Studies, 36(2), pp. 1-21, 2013.

[30] Mukhopadhyay, D.P. \& Chakraverty, R.K., Plant Wealth of the Raj Bhavan Kolkata, 2008.

[31] Sarkar, A.K., Taxonomic and ecological studies on the amphibians of Calcutta and its environs. Rec. Zoological Survey of India, 81(3-4), pp. 215-236, 1984.

[32] Bandyopadhyay, K., Greying Kolkata's green cover in free fall, The Times of India, City Online. http://timesofindia.indiatimes.com/city/kolkata/Greying-Kolkatas-greencover-in-free-fall/articleshow/46912398.cms. Accessed on: 2 May 2015.

[33] ENDEV, Report on status of Calcutta's parks and gardens with an integrated management plan, ENDEV, Society for Environment and Development, Unpublished, 2001.

[34] Kolkata Municipal Corporation, Directory of Parks of Kolkata, 2012.

[35] Chatterjee, S., Kolkata Municipal Corporation: Budget Statement: 2015-2016, Central Municipal Office, 2015. 
[36] Kolkata Metropolitan Development Authority, Annual Report 2011, 2011.

[37] Final Report: Kolkata Urban Sector Investment Plan (2012-2022), Vol. 1, Kolkata Environmental Improvement Project, Mar. 2012.

[38] Ghosh, A.K., Urban Ecology - A Case study of Calcutta, Institute of Local Government \& Urban Studies, Government of West Bengal, 1987.

[39] Ghosh, S., The urban pattern of Calcutta, India. Economic Geography, 26(1), pp. 51$58,1950$.

[40] Bhattacharjee, C., Canals and its relevance to the Kolkata Mega City. Abhinav National Monthly Refereed Journal of Research in Arts \& Education, III(5), pp. 20 24, 2014.

[41] Weather Atlas, Kolkata, India - Climate data, Online. http://www.weatheratlas.com/en/india/kolkata-climate. Accessed on: 4 Apr. 2017.

[42] Economy of Kolkata, Online. https://en.wikipedia.org/wiki/Economy_of_Kolkata. Accessed on: 25 May 2016.

[43] Top 10 richest City in India - The Fast Growing Cities of India Online. http://www.pincodeindia.net/top-10-richest-city-in-india.php. Accessed on: 25 May 2016. 